\title{
Biogas potential from forbs and grass-clover mixture with the application of near infrared spectroscopy
}

\author{
Radziah Wahid $^{\mathrm{a}, \mathrm{b}, *}$, Alastair James Ward ${ }^{\mathrm{a}}$, Henrik Bjarne Møller ${ }^{\mathrm{a}}$, Karen Søegaard ${ }^{\mathrm{c}}$, Jørgen Eriksen ${ }^{\mathrm{c}}$ \\ ${ }^{a}$ Department of Engineering, Aarhus University, Blichers Allé 20, DK 8830 Tjele, Denmark \\ ${ }^{\mathrm{b}}$ Faculty of Chemical Engineering, Universiti Teknologi Mara, 40450 Shah Alam, Malaysia \\ ' Department of Agroecology, Aarhus University, Blichers Allé 20, DK 8830 Tjele, Denmark
}

\section{H I G H L I G H T S}

- Potential of pure stand forbs as substrates for biogas production is emphasised.

- Cutting strategy influenced biogas yields and chemical compositions.

- NIRS as a successful tools for predicting biogas yield and plants compositions.

- Inclusion of forbs in grassland may potentially lead to higher methane production.

\section{A R T I C L E I N F O}

\section{Article history:}

Received 11 July 2015

Received in revised form 26 August 2015

Accepted 27 August 2015

Available online 11 September 2015

\section{Keywords:}

Forbs

Cutting strategy

Biogas

Near infrared spectroscopy

\begin{abstract}
A B S T R A C T
This study investigated the potentials of forbs; caraway, chicory, red clover and ribwort plantain as substrates for biogas production. One-, two- and four-cut systems were implemented and the influence on dry matter yields, chemical compositions and methane yields were examined. The two- and four-cut systems resulted in higher dry matter yields ( $\mathrm{kg}$ [total solid, TS] ha ${ }^{-1}$ ) compared to the one-cut system. The effect of plant compositions on biogas potentials was not evident. Cumulative methane yields $\left(\mathrm{LCH}_{4} \mathrm{~kg}^{-1}\right.$ [volatile solid, VS]) were varied from 279 to 321 (chicory), 279 to 323 (caraway), 273 to 296 (ribwort plantain), 263 to 328 (red clover) and 320 to 352 (grass-clover mixture), respectively. Methane yield was modelled by modified Gompertz equation for comparison of methane production rate. Near infrared spectroscopy showed potential as a tool for biogas and chemical composition prediction. The best prediction models were obtained for methane yield at 29 days (99 samples), cellulose, acid detergent fibre, neutral detergent fibre and crude protein, $\left(R^{2}>0.9\right)$.
\end{abstract}

(c) 2015 Elsevier Ltd. All rights reserved.

\section{Introduction}

Forb, a herbaceous flowering dicotyledonous plant; often sown in organic grasslands to improve herbage mineral content and increase biodiversity (Elgersma et al., 2013; Pirhofer-Walzl et al., 2011). Forbs are also used as forage crops for livestock (Marley et al., 2014) and some species are used in traditional medicine (Pirhofer-Walzl et al., 2011). In Denmark, forbs are planted together with grass-clover mixtures to improve the ecosystems and sustainability of the grasslands (Søegaard et al., 2011). Søegaard et al. (2011) reported that including forbs in grassland could increase the biodiversity without affecting the dry matter yield. The results indicated that plant species greatly influenced

\footnotetext{
* Corresponding author at: Department of Engineering, Aarhus University, Blichers Allé 20, DK 8830 Tjele, Denmark. Tel.: +45 60243382.

E-mail address: Radziah.Wahid@eng.au.dk (R. Wahid).
}

the growth, competitiveness and herbage quality of forbs. Chicory, caraway and ribwort plantain were the main competitors as the plant yields were high when sown with grass-clover mixture. Besides, caraway has higher digestibility of organic matter than grassland mixture and other forbs.

Plants such as reed canary, wheat straw and miscanthus have been investigated for biogas potentials (Kaparaju et al., 2010; Klimiuk et al., 2010; Oleszek et al., 2014; Seppälä et al., 2009) however, forbs are less exploited. The knowledge concerning the biogas potentials from forbs is essential as it may further increase the beneficial value of the plant species. Thus, the examination of biogas potentials from chicory, caraway and ribwort plantain is the main highlight in the present study. Red clover and grass-clover mixture are also tested for biogas production, mainly for comparison purposes with chicory, caraway and ribwort plantain. Forbs are usually grown as part of a mixture with other plant species in grasslands, but in this study we first focus on examining the 
biogas potentials from pure stand forbs. In addition, the influence of cutting strategy on dry matter yield, chemical composition and biogas yield were evaluated as plants were cut at three different strategies. Cutting strategy is an important factor as it can influence the compositions of the plants, which may lead to differences in organic matter digestibility and fibre composition which may, in turn, affect biogas yields (Mähnert et al., 2005). The perspective is to produce biomass for energy in combination with flowering species in the mixtures, which may be obtained by performing fewer cuts per year than the traditional four to five cuts per year. Besides, fewer cuts will allow forbs to produce flowers as the nectar is important to feed the pollinators in grasslands. Thus, it is important to investigate the biogas potential of individual species under different cutting regimes. It is hypothesised that systems with only one or two cuts per year display only a limited decline in gas yields on a per-hectare basis compared to a four cut strategy, thus lowering the costs per unit biogas produced.

This study also investigated the potential of near infrared spectroscopy (NIRS) as a tool to predict chemical composition and biogas yield of the plant samples. NIRS is a spectroscopic method using the infrared region of the electromagnetic spectrum (800$2500 \mathrm{~nm}$ ) (Doublet et al., 2013). Generally, tedious experimental procedures are followed to measure chemical compositions such as carbon, nitrogen, lignin, cellulose and hemicelluloses of plants and batch test anaerobic digestion is initiated to measure the biogas potentials (Doublet et al., 2013). These laboratory tests are time consuming (the biogas batch test typically takes 30-90 days) and requires sample preparation which contrast to NIRS, as the latter requires no sample preparation and is a fast and easy method (Kandel et al., 2013a; Krapf et al., 2011). Principally, chemical compositions and biogas yield were predicted by NIRS based on the spectra produced from the samples. The complex organic matter such as carbohydrate, protein and fats inside the samples created their own blueprints, allowing quantification of chemical compositions and biogas yield using NIRS (Mayer et al., 2011). Thus, we hypothesise that NIRS can predict biogas potentials across plant species with widely different characteristics.

\section{Methods}

\subsection{Field experiment}

Pure stand of chicory (Cicorium intybus L.), caraway (Carum carvi L.), ribwort plantain (Plantago lanceolata L.) and red clover (Trifolium pratense L.) and grass-clover mixture (perennial rye-grass (Lolium perenne L.), red and white clover (Trifolium repens L.) were planted in existing fields experiments at Research Center Foulum, Aarhus University, Tjele, Denmark in 2011. The experimental plots were located in a dairy crop rotation experiment of Aarhus University at Foulum $\left(9^{\circ} 34^{\prime} \mathrm{E}, 56^{\circ} 29^{\prime} \mathrm{N}\right)$, with mean annual rainfall of $770 \mathrm{~mm}$ and mean annual temperature of $7.7^{\circ} \mathrm{C}$. Since 1987 the site has had intensive dairy farming with grassland-arable crop rotations (Eriksen et al., 1999, 2004). The soil is classified as a typical hapludult with $6.4 \%$ clay, $8.5 \%$ silt, $44 \%$ fine sand, $39 \%$ coarse sand and $1.6 \%$ carbon. The plants were sown at $25 \mathrm{~kg} \mathrm{ha}^{-1}$ in plot of $1.5 \times 10 \mathrm{~m}$, with three replicates each. Plots were managed without application of fertilizer and the samples used in this study were harvested in 2013 (second year harvest). In 2012, only two cutting strategies were implemented (one- and four-cut system), while in 2013, three cutting strategies were applied (one-, twoand four-cut system). Cutting strategy one; plants were harvested once in October (1/1), cutting strategy two; plants were cut twice, July $(1 / 2)$ and October $(2 / 2)$, and cutting strategy three; plants were harvested four times, May (1/4), July (2/4), August (3/4) and October (4/4). For red clover, it was only possible to establish two cutting strategies (one- and four-cut system). The plots were cut at $7 \mathrm{~cm}$ stubble height using a Haldrup plot harvester (J. Haldrup a/s, Løgstør, Denmark). During the experiment, the weather data was recorded daily.

\subsection{Biomass preparation}

Forbs and clover grass mixture were dried in a $60{ }^{\circ} \mathrm{C}$ oven for $48 \mathrm{~h}$ before grinding to $0.8 \mathrm{~mm}$ particle size using a Foss mill (FOSS Cyclotec $^{\mathrm{TM}}$ 1093). The dried powder was stored and sealed in airtight bottles under ambient temperature for further usage; composition analysis, biogas test and NIRS analysis. The VS of samples were analysed following the procedure described by (APHA, 2005).

\subsection{Sample analysis}

\subsubsection{Biogas}

Inoculum was collected from a mesophilic post digester at the full-scale biogas plant in Research Centre Foulum, Aarhus University, Denmark. Inoculum was stored 3 weeks at $35{ }^{\circ} \mathrm{C}$ to ensure the biogas production from inoculum was minimised. The inoculum was filtered using a manual sieve to remove the larger particles. The average TS and VS of the inoculum were $3.4 \%$ and $2.4 \%$ respectively.

The batch test was done as described by (Møller et al., 2004). Firstly, the dried plant materials for the three field replicates were pooled. About $200 \mathrm{~g}$ of inoculum was added in each $500 \mathrm{~mL}$ infusion bottle, followed by the addition of substrate with a ratio of $1: 1$ (VS $\left._{\text {substrate }}: \mathrm{VS}_{\text {inoculum }}\right)$ in three replicates. A control with only inoculum was included. The bottles were incubated at $35^{\circ} \mathrm{C}$ for 90 days. The measurement of biogas volume was done by inserting a needle connected to a tube with inlet to a column filled with acidified water $(\mathrm{pH}<2)$ through the butyl rubber. The biogas produced was calculated by the water displaced until the two pressures (column and headspace in bottles) were equal. Biogas compositions were analysed by using gas chromatography (7890A, Agilent Technologies, USA). Methane produced from each sample was corrected by subtracting the volume of methane produced from the inoculum control. The resulting specific methane yields were normalised to standard conditions (gas volume corrected to $0{ }^{\circ} \mathrm{C}$ and 1.013 bar).

\subsubsection{Composition analysis}

Cellulose, hemicelluloses and lignin composition of the plant samples were determined by measuring the value of acid detergent fibre (ADF), neutral detergent fibre (NDF) and acid detergent lignin (ADL) of the plant. Cellulose was calculated as the difference between ADF and ADL, hemicelluloses as the difference between NDF and ADF. The analysis followed the Van Soest method (Van Soest et al., 1991). Ash was determined after combustion at $525^{\circ} \mathrm{C}$ for $6 \mathrm{~h}$ and nitrogen $(\mathrm{N})$ content in forbs and grass-clover mixture was analysed following the Dumas method. Crude protein (CP) was calculated as $6.25 \times \mathrm{N}$ (Elgersma et al., 2013). All samples were analysed in duplicate.

\subsubsection{NIRS spectra acquisition}

For standardisation, dried plant samples used in batch test and chemical compositions analyses were also used for NIRS analysis. The dried sample was loaded into a glass tube until the powder filled three quarter of the tube. The surface of the tube was cleaned and placed into a rotating powder sampler that was attached to the NIRS spectrometer. The samples were scanned using a Bomem QFA Flex Fourier Transform Spectrometer fitted with an InAs detector (Q-interline A/S, Copenhagen, Denmark). Each sample was scanned 256 times using $32 \mathrm{~cm}^{-1}$ resolutions. The models for biogas and methane prediction were built by using both triplicates (99 data 
samples) and average values (33 data samples) from batch test. Models based on chemical compositions were built using only the individual 33 samples.

\subsection{Data analysis}

Data collected from the experiment were calculated and further analysed by using online Pearson correlation and ASSISTAT version 7.7 beta. A description of the Pearson correlation can be found in (Wessa, 2012) and for the ASSISTAT software in Silva and Azevedo (2006).

The methane yield production at 90 days was modelled by fitting the experimental data to a modified Gompertz model (Eq. (1)):

$y=A \exp \left\{-\exp \left[\mu_{\mathrm{m}} e / A(\lambda-T)+1\right]\right\}$

where $y=$ cumulative methane yield $\left(\mathrm{LCH}_{4} \mathrm{~kg}^{-1} \mathrm{VS}\right) ; A=$ maximum methane production potential $\left(\mathrm{LCH}_{4} \mathrm{~kg}^{-1} \mathrm{VS}\right) ; \mu_{\mathrm{m}}=$ methane production rate $\left(\mathrm{LCH}_{4} \mathrm{~kg}^{-1} \mathrm{VS} \mathrm{d}^{-1}\right) ; e=$ Euler's constant, 2.71828183; $\lambda=$ the lag phase period or the minimum time required to produce methane (days); $T$ = time (days) (Lo et al., 2010).

The analysis was performed in Microsoft excel using the solver feature. From the modified Gompertz model, methane production rate $\left(\mu_{\mathrm{m}}\right)$ and lag phase $(\lambda)$ were determined. Squared correlation coefficient $\left(R^{2}\right)$ was used to evaluate the precision of the model fit. Statistical analysis was estimated using ANOVA (factorial experiment) and carried out through ASSISTAT software.

For NIRS analysis, the prediction models were developed using The Unscrambler software, version 9.8, (CAMO Software A/S, Oslo, Norway). Models were based on partial least squares (PLS) regression for single parameter prediction - PLS1 with full leave-one-out cross validation procedure. The entire spectral range measured by the spectrometer was $1990-15,599 \mathrm{~cm}^{-1}$. After removing the noise regions, the spectral range was reduced from $3718 \mathrm{~cm}^{-1}$ to $8000 \mathrm{~cm}^{-1}$, and this range is hereafter referred to as raw data. Various pre-processing treatments; multiplicative scatter correction (MSC), standard normal variate (SNV), baseline offset and Savitzky-Golay derivative were applied to the raw data to reduce the baseline variation and enhanced spectral features. The quality of each model was evaluated based on the coefficient of determination $\left(R^{2}\right)$ and the root mean square error of cross validation (RMSE $\mathrm{CV}_{\mathrm{CV}}$ ). High $R^{2}$ and low RMSE $\mathrm{CV}$ is desirable in the model. Residual prediction deviation (RPD) was also calculated and details were explained in Raju et al., 2011.

\section{Results and discussion}

\subsection{Dry matter yields, TS and VS content}

The characteristics of the forbs and grass-clover mixture used in this study are summarised in Table 1 . As observed, the grass-clover mixture had the highest average DM yield followed by red clover, ribwort plantain/caraway and chicory. The average DM yields of chicory, caraway and ribwort plantain were varied from 2523 to $3024 \mathrm{~kg} \mathrm{ha}^{-1}$ (cut $1 / 1$ ), 4489 to $5777 \mathrm{~kg} \mathrm{ha}^{-1}$ (cut $1 / 2$ and $2 / 2$ ) and 3907 to $5793 \mathrm{~kg} \mathrm{ha}^{-1}$ (cut 1/4, 2/4,3/4 and 4/4). Elgersma et al. (2013) observed higher average DM yield of chicory $\left(9960 \mathrm{~kg} \mathrm{ha}^{-1}\right)$ and ribwort plantain $\left(8416 \mathrm{~kg} \mathrm{ha}^{-1}\right)$ while, the average DM yield of caraway was comparable to this study. In the previous study, the average DM yields were estimated based on the DM yields of forbs harvested in 2009 and 2010 (first and second harvesting year) over four cuts. The forbs were cut in May, July, August and October; comparable to the present study. These harvesting periods corresponded with the standard grass harvesting time of a four-cut strategy in Denmark (Elgersma et al., 2013).
The average DM yields of forbs and grass-clover mixture were elevated when cutting strategy two and three were implemented. For chicory, ribwort plantain and grass-clover mixture, average DM yields were higher when the plants were harvested twice. It was observed that when forbs (except caraway) and grass-clover mixture were cut four times, the average DM yield and TS content from the July harvest was greater than May, August and October harvest. This observation possibly related to the weather conditions (Fig. 1); high temperature $\left(16.7^{\circ} \mathrm{C}\right)$ and high mean global radiation $\left(21 \mathrm{MJ} \mathrm{mm}^{-2}\right)$, and low precipitation $(16.9 \mathrm{~mm})$ were examined in July 2013 compared to other months. In contrast, plants harvested in May 2013 had lowest average DM yield and TS due to late spring and low April temperature $\left(5.1^{\circ} \mathrm{C}\right)$. The VS content of the plants varied from $85 \%$ to $94 \%$ of the DM.

\subsection{Chemical compositions}

The $\mathrm{C}$ and $\mathrm{CP}$ content, and fibre compositions (cellulose, hemicelluloses and lignin) of forbs and grass-clover mixture were shown in Table 1 and Fig. 2a-e. From the results, it was observed that the plants from first harvest of one- and two-cut system contained lower CP content than plants from first harvest of four-cut system. As reported by Kamalak et al. (2005) and Buxton (1996), the percentage of $\mathrm{CP}$ in alfalfa, white and red clover, and tumbleweed hay (stem and leaf) decreased with advancing maturity and the result in the present study was in agreement with this observation. Besides, the $\mathrm{CP}$ content was also lower when the plants were cut in July 2013 in four-cut system. For C content, only small variations were observed (41-46\%) when different cutting strategies were applied.

Generally, fibre content of forbs and grass-clover mixture was higher when yield and morphological stage of the plants increased. This explained higher fibre content of plants from the first harvest of one- and two-cut systems than the other harvest time. In the four-cut system, variations in fibre compositions of the plants were pronounced and this probably because of the weather conditions during growth. High temperature and high global radiation in July 2013 might be the reason for the high fibre content at the second cut. Fibre content in first harvest of four-cut system was lower due to temperatures lower than normal in April 2013. In addition, low average DM yield in May 2013 caused low NDF values for the plants. Nevertheless, the observation was diverse for grass-clover as the first cut had higher fibre content compared to third and forth cut. Perennial rye grass is a monocotyledon while the forbs are dicotyledon. Monocotyledon plant consists of higher NDF content than dicotyledon plant. During the first cut, the percentage of perennial rye grass in the mixture was higher (82\%) than second (68\%), third (30\%) and forth (37\%) cut. This clarified high content of fibre during the first cut as the major proportion of the mixture is perennial rye grass. Concerning cellulose and hemicelluloses, ribwort plantain had lower content than other forbs and grassclover mixture and thus a reduced methane yield (Table 1). As expected, grass-clover mixture contained more cellulose and hemicelluloses, and less lignin content, causing higher production of methane than the forbs.

The relationship between cellulose vs. hemicelluloses, cellulose vs. lignin and hemicelluloses vs. lignin of forbs and grass-clover mixture were correlated by Pearson correlation coefficient. In general, a positive correlation between cellulose and lignin was observed for forbs (except caraway) with $R^{2}$ values higher than 0.7. Cellulose content increased linearly with the increment in hemicelluloses content and this was true for all samples except chicory. The relationship between hemicelluloses and lignin was only pronounced in red clover where a positive correlation with $R^{2}>0.8$ was observed. Nevertheless, no specific trend was 
Table 1

Characteristics of forbs and grass-clover mixture at different cutting period.

\begin{tabular}{|c|c|c|c|c|c|c|c|c|c|c|c|}
\hline \multirow[t]{2}{*}{ Species } & \multirow[t]{2}{*}{$\begin{array}{l}\text { Cutting } \\
\text { strategy }\end{array}$} & \multirow[t]{2}{*}{$\begin{array}{l}\text { Harvest } \\
\text { date }\end{array}$} & \multicolumn{2}{|c|}{$\begin{array}{l}\text { Cumulative methane } \\
\text { yield }\left(\mathrm{LCH}_{4} \mathrm{~kg}^{-1} \mathrm{VS}\right)\end{array}$} & \multicolumn{2}{|c|}{$\begin{array}{l}\text { Biogas yield" } \\
\left(\mathrm{LCH}_{4} \mathrm{~kg}^{-1} \mathrm{VS}\right)\end{array}$} & \multirow[t]{2}{*}{$\begin{array}{l}\text { Dry matter yield } \\
\left(\mathrm{kg} \mathrm{ha}^{-1}\right)\end{array}$} & \multirow[t]{2}{*}{$\begin{array}{l}\text { Total solid } \\
\text { (TS) }\end{array}$} & \multirow[t]{2}{*}{$\begin{array}{l}\text { Volatile Solid } \\
\text { (VS) }\end{array}$} & \multirow[t]{2}{*}{$\begin{array}{l}\text { Crude protein } \\
\text { (CP) }\end{array}$} & \multirow[t]{2}{*}{$\begin{array}{l}\text { Carbon } \\
\text { (C) }\end{array}$} \\
\hline & & & 29 days & 90 days & 29 days & 90 days & & & & & \\
\hline \multirow[t]{7}{*}{ Chicory } & Cut $1 / 1$ & $10 / 10 / 2013$ & $245 \pm 5 d$ & $279 \pm 10 b$ & $472 \pm 12 c$ & $539 b \pm 18$ & $2695 \pm 851$ & $27 \pm 4$ & $88 \pm 1$ & 7 & 43.2 \\
\hline & Cut $1 / 2$ & $12 / 7 / 2013$ & $294 \pm 8 a b$ & $321 \pm 19 a$ & $576 \pm 15 a b$ & $625 a \pm 36$ & $3386 \pm 1049$ & $19 \pm 2$ & $88 \pm 2$ & 6.3 & 44.3 \\
\hline & Cut $2 / 2$ & $10 / 10 / 2013$ & $275 \pm 6 c$ & $301 \pm 6 a b$ & $539 \pm 17 b$ & $586 a b \pm 16$ & $1103 \pm 780$ & $22 \pm 2$ & $89 \pm 0$ & 7.9 & 43.2 \\
\hline & Cut $1 / 4$ & $29 / 05 / 2013$ & $287 \pm 12 \mathrm{abc}$ & $308 \pm 20 a b$ & $549 \pm 21 b$ & $583 a b \pm 33$ & $1042 \pm 164$ & $12 \pm 1$ & $87 \pm 0$ & 24.4 & 43.1 \\
\hline & Cut $2 / 4$ & $12 / 7 / 2013$ & $304 \pm 4 a$ & $326 \pm 6 a$ & $597 \pm 9 a$ & $636 a \pm 11$ & $2113 \pm 1134$ & $20 \pm 2$ & $87 \pm 5$ & 8.5 & 43.2 \\
\hline & Cut $3 / 4$ & $20 / 08 / 2013$ & $276 \pm 4 \mathrm{bc}$ & $299 \pm 9 a b$ & $545 \pm 8 b$ & $583 a b \pm 16$ & $522 \pm 360$ & $15 \pm 1$ & $88 \pm 0$ & 12.1 & 42.3 \\
\hline & Cut $4 / 4$ & 8/10/2013 & $291 \pm 2 a b c$ & $313 \pm 3 a b$ & $578 \pm 11 a b$ & $614 a \pm 5$ & $230 \pm 189$ & $18 \pm 2$ & $88 \pm 0$ & 13.3 & 42.4 \\
\hline \multirow[t]{7}{*}{ Caraway } & Cut $1 / 1$ & $10 / 10 / 2013$ & $270 \pm 9 b$ & $311 \pm 12 b$ & $459 \pm 17 b$ & $531 \pm 20 b$ & $2523 \pm 197$ & $35 \pm 7$ & $94 \pm 0$ & 7.8 & 45.8 \\
\hline & Cut $1 / 2$ & $12 / 7 / 2013$ & $291 \pm 2 a$ & $323 \pm 4 a b$ & $558 \pm 9 a$ & $619 \pm 11 \mathrm{a}$ & $4450 \pm 902$ & $24 \pm 1$ & $93 \pm 0$ & 7.8 & 45.5 \\
\hline & Cut $2 / 2$ & $10 / 10 / 2013$ & $219 \pm 3 c$ & $308 \pm 9 b c$ & $488 \pm 7 b$ & $615 \pm 16 a$ & $716 \pm 313$ & $18 \pm 3$ & $88 \pm 0$ & 16.7 & 43.1 \\
\hline & Cut $1 / 4$ & $29 / 05 / 2013$ & $296 \pm 6 a$ & $348 \pm 10 \mathrm{a}$ & $577 \pm 20 \mathrm{a}$ & $653 \pm 12 a$ & $3128 \pm 58$ & $11 \pm 1$ & $88 \pm 0$ & 17.8 & 42.3 \\
\hline & Cut $2 / 4$ & $12 / 7 / 2013$ & $234 \pm 9 c$ & $279 \pm 17 c$ & $448 \pm 20 \mathrm{~b}$ & $518 \pm 31 b$ & $1749 \pm 733$ & $19 \pm 1$ & $91 \pm 0$ & 10.5 & 43.7 \\
\hline & Cut $3 / 4$ & $20 / 08 / 2013$ & $191 \pm 8 d$ & $304 \pm 10 b c$ & $459 \pm 11 b$ & $618 \pm 10 \mathrm{a}$ & $394 \pm 280$ & $17 \pm 1$ & $86 \pm 1$ & 17.3 & 43.1 \\
\hline & Cut $4 / 4$ & $8 / 10 / 2013$ & $227 \pm 11 c$ & $302 \pm 11 b c$ & $496 \pm 39 b$ & $601 \pm 30 a$ & $522 \pm 385$ & $18 \pm 3$ & $87 \pm 1$ & 17.1 & 42.7 \\
\hline \multirow[t]{7}{*}{ Ribwort plantain } & Cut $1 / 1$ & $10 / 10 / 2013$ & $255 \pm 5 a$ & $290 \pm 8$ & $476 \pm 11 \mathrm{ab}$ & $539 \pm 14$ & $3024 \pm 955$ & $35 \pm 1$ & $90 \pm 0$ & 12.7 & 43.8 \\
\hline & Cut $1 / 2$ & $12 / 7 / 2013$ & $259 \pm 6 a$ & $295 \pm 11$ & $493 \pm 13 a$ & $556 \pm 23$ & $4187 \pm 765$ & $21 \pm 2$ & $93 \pm 0$ & 7.9 & 43.8 \\
\hline & Cut $2 / 2$ & $10 / 10 / 2013$ & $260 \pm 3 a$ & $296 \pm 9$ & $496 \pm 4 a$ & $557 \pm 12$ & $1590 \pm 551$ & $25 \pm 4$ & $90 \pm 0$ & 12.1 & 43.5 \\
\hline & Cut $1 / 4$ & $29 / 05 / 2013$ & $243 \pm 6 a b$ & $276 \pm 14$ & $476 \pm 13 a b$ & $528 \pm 25$ & $1449 \pm 275$ & $11 \pm 1$ & $87 \pm 0$ & 22.2 & 41.7 \\
\hline & Cut $2 / 4$ & $12 / 7 / 2013$ & $251 \pm 3 a b$ & $289 \pm 6$ & $481 \pm 6 a b$ & $546 \pm 9$ & $2831 \pm 421$ & $20 \pm 1$ & $92 \pm 0$ & 8.8 & 43.9 \\
\hline & Cut $3 / 4$ & $20 / 08 / 2013$ & $236 \pm 6 b$ & $273 \pm 12$ & $455 \pm 13 a b$ & $516 \pm 22$ & $782 \pm 662$ & $19 \pm 1$ & $90 \pm 0$ & 12.9 & 43.4 \\
\hline & Cut $4 / 4$ & $8 / 10 / 2013$ & $210 \pm 13 c$ & $289 \pm 9$ & $442 \pm 31 b$ & $555 \pm 4$ & $561 \pm 384$ & $21 \pm 4$ & $90 \pm 0$ & 13.5 & 42.9 \\
\hline \multirow[t]{5}{*}{ Red clover } & Cut $1 / 1$ & $10 / 10 / 2013$ & $238 \pm 5 b$ & $263 \pm 10 b$ & $420 \pm 9 b$ & $465 \pm 18 b$ & $5294 \pm 642$ & $43 \pm 12$ & $94 \pm 0$ & 13.5 & 46 \\
\hline & Cut $1 / 4$ & $29 / 05 / 2013$ & $293 \pm 7 a$ & $328 \pm 4 a$ & $544 \pm 21 \mathrm{a}$ & $599 \pm 15 a$ & $2357 \pm 355$ & $12 \pm 0$ & $91 \pm 0$ & 24.5 & 44.7 \\
\hline & Cut $2 / 4$ & $12 / 7 / 2013$ & $278 \pm 10 \mathrm{a}$ & $306 \pm 17 a$ & $527 \pm 22 a$ & $572 \pm 33 a$ & $3176 \pm 1328$ & $19 \pm 3$ & $93 \pm 0$ & 14.9 & 44.5 \\
\hline & Cut $3 / 4$ & $20 / 08 / 2013$ & $275 \pm 1 \mathrm{a}$ & $309 \pm 2 a$ & $509 \pm 5 a$ & $564 \pm 5 a$ & $1228 \pm 184$ & $15 \pm 1$ & $92 \pm 0$ & 22.4 & 45.4 \\
\hline & Cut $4 / 4$ & $8 / 10 / 2013$ & $284 \pm 7 a$ & $316 \pm 13 a$ & $513 \pm 11 a$ & $564 \pm 21 a$ & $1097 \pm 47$ & $18 \pm 0$ & $92 \pm 0$ & 25 & 46 \\
\hline \multirow{7}{*}{$\begin{array}{l}\text { Grass-clover mixture } \\
\text { (red, white clover and } \\
\text { rye-grass) }\end{array}$} & Cut $1 / 1$ & $10 / 10 / 2013$ & $281 \pm 6 b$ & $320 \pm 6 b$ & $505 \pm 11 c$ & $575 \pm 11 c$ & $4709 \pm 384$ & $34 \pm 5$ & $94 \pm 0$ & 12.5 & 45.3 \\
\hline & Cut $1 / 2$ & $12 / 7 / 2013$ & $305 \pm 4 a$ & $331 \pm 8 \mathrm{ab}$ & $587 \pm 4 a b$ & $633 \pm 12 \mathrm{ab}$ & $6143 \pm 181$ & $31 \pm 2$ & $95 \pm 0$ & 6.7 & 44.5 \\
\hline & Cut $2 / 2$ & $10 / 10 / 2013$ & $305 \pm 10 \mathrm{a}$ & $333 \pm 11 a b$ & $569 \pm 27 a b$ & $615 \pm 28 \mathrm{abc}$ & $2407 \pm 355$ & $22 \pm 2$ & $91 \pm 0$ & 15.7 & 44.3 \\
\hline & Cut $1 / 4$ & $29 / 05 / 2013$ & $315 \pm 4 a$ & $352 \pm 10 \mathrm{a}$ & $603 \pm 12 a$ & $657 \pm 11 \mathrm{a}$ & $2923 \pm 128$ & $13 \pm 1$ & $91 \pm 0$ & 18.1 & 43.5 \\
\hline & Cut $2 / 4$ & $12 / 7 / 2013$ & $315 \pm 9 a$ & $342 \pm 10 \mathrm{ab}$ & $592 \pm 22 a b$ & $636 \pm 25 a b$ & $3082 \pm 827$ & $22 \pm 0$ & $93 \pm 0$ & 12.2 & 44.4 \\
\hline & Cut $3 / 4$ & $20 / 08 / 2013$ & $297 \pm 9 a b$ & $324 \pm 13 b$ & $550 \pm 13 \mathrm{bc}$ & $593 \pm 18 \mathrm{bc}$ & $1156 \pm 103$ & $15 \pm 1$ & $90 \pm 0$ & 22 & 44.8 \\
\hline & Cut $4 / 4$ & 8/10/2013 & $308 \pm 3 a$ & $338 \pm 2 \mathrm{ab}$ & $576 \pm 15 a b$ & $622 \pm 12 \mathrm{abc}$ & $1185 \pm 211$ & $18 \pm 1$ & $90 \pm 0$ & 20.2 & 44.8 \\
\hline
\end{tabular}

\pm represents standard deviation; methane and biogas yield deviation are based on batch test replicates while, harvest yield, TS, VS, CP and C is based on plot replicates.

Means followed by different letter, ${ }^{\text {a-d }}$ in the row differ by Tukey test at 0.05 of probability. 


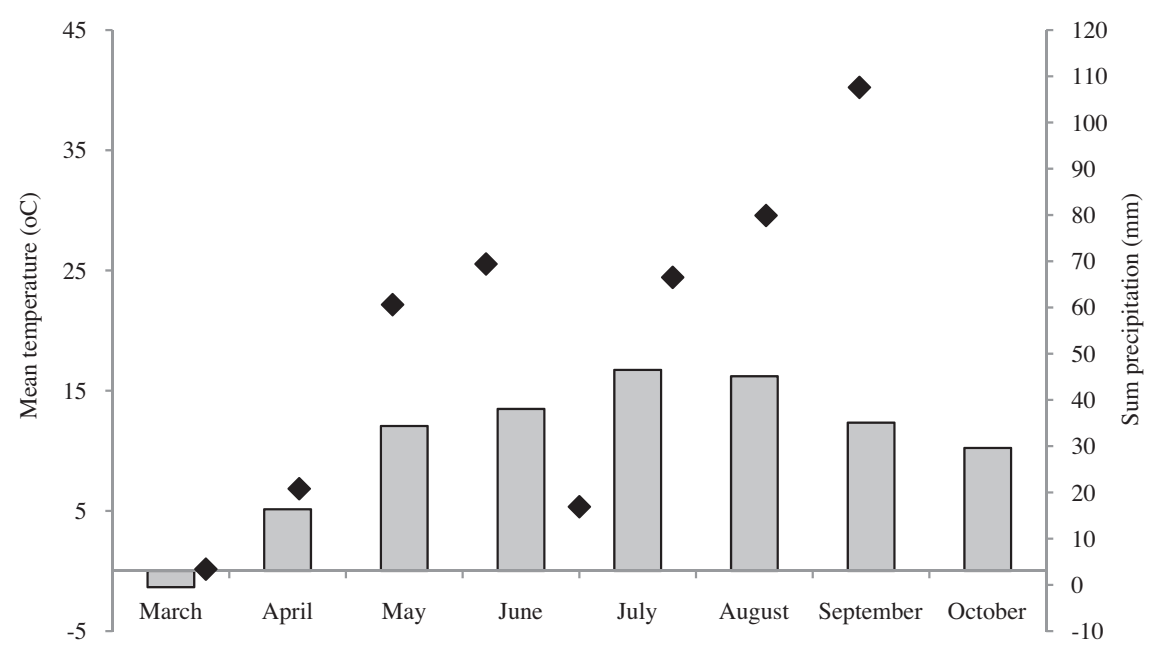

Fig. 1. Climate conditions during harvesting period at Foulum, Viborg Denmark.

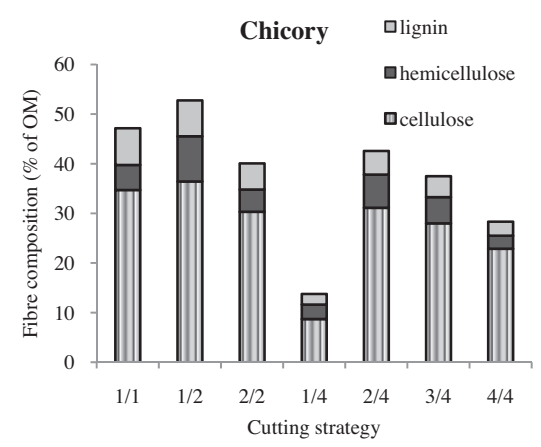

(a)

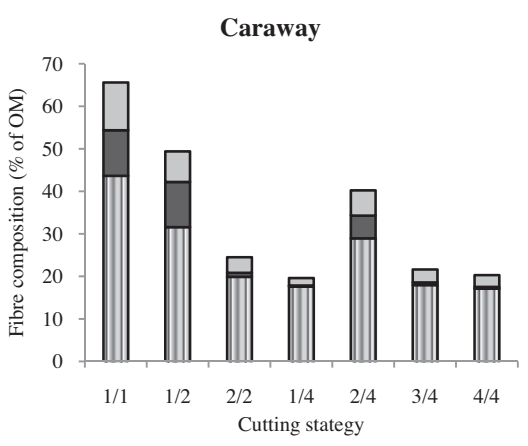

(b)

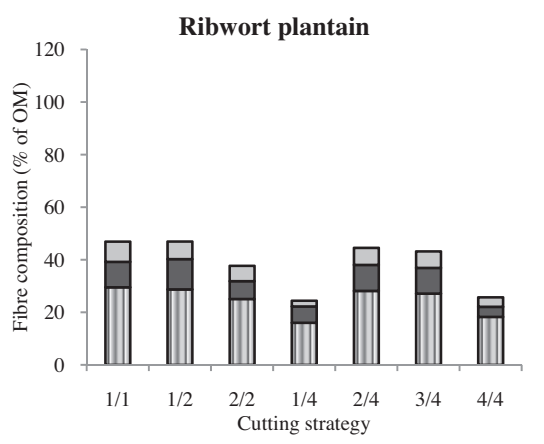

(c)

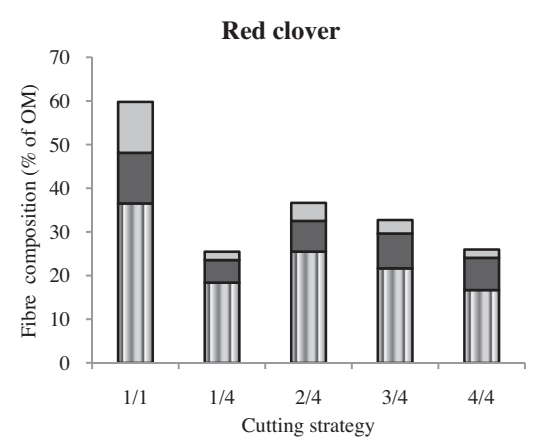

(d)

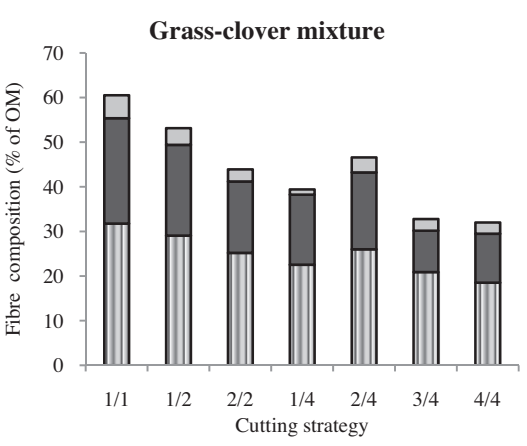

(e)

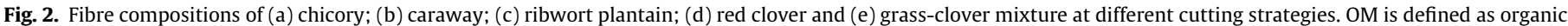
matter.

observed (cellulose vs. hemicelluloses, cellulose vs. lignin and hemicelluloses vs. lignin) when all samples were examined in the same curve.

\subsection{Specific methane yield}

Methane production from forbs and grass-clover mixture after 90 days anaerobic digestion are presented in Table 1 and Fig. 3a-e. From Table 1, cumulative methane yields of the plants after 90 days anaerobic digestion varied from 279 to 326 $\mathrm{LCH}_{4} \mathrm{~kg}^{-1} \mathrm{VS}$ (chicory), 279 to $348 \mathrm{LCH}_{4} \mathrm{~kg}^{-1} \mathrm{VS}$ (caraway), 273 to $296 \mathrm{LCH}_{4} \mathrm{~kg}^{-1} \mathrm{VS}$ (ribwort plantain), 263 to $328 \mathrm{LCH}_{4} \mathrm{~kg}^{-1} \mathrm{VS}$ (red clover) and 320 to $352 \mathrm{LCH}_{4} \mathrm{~kg}^{-1} \mathrm{VS}$ (grass-clover mixture). The methane yield of grass-clover mixture and forbs deviates slightly; suggesting differences of pure stand and mixture samples. Moreover, the amount of methane produced by caraway and chicory were comparable with red clover.

Fig. 3a, d and e shows methane yield curves for chicory, red clover and grass-clover mixture. A clear trend illustrating plants harvested with the one-cut system had a lower methane yield than two- and four-cut systems. This can be explained by the late harvesting period (October 2013) during one-cut system which increased plant maturity. As reported by Dien et al. (2006), the amount of lignin in the cell wall increases linearly with plant 


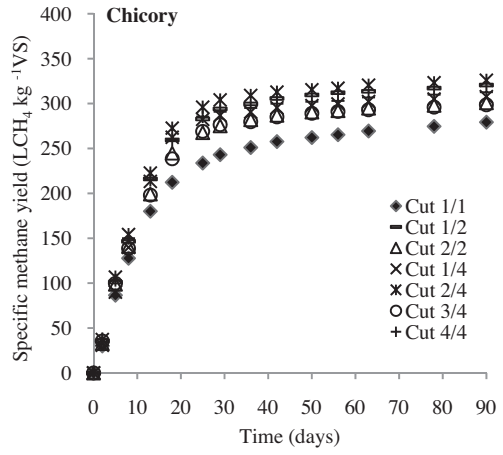

(a)

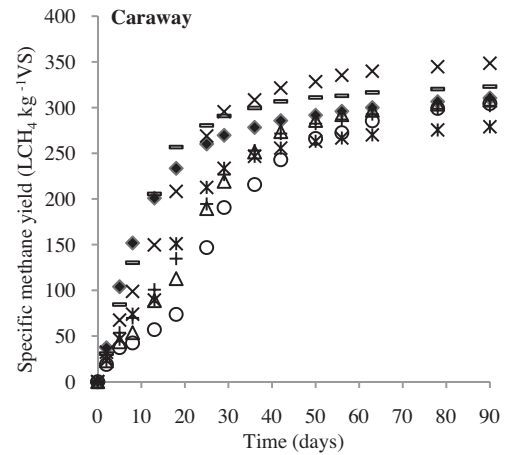

(b)

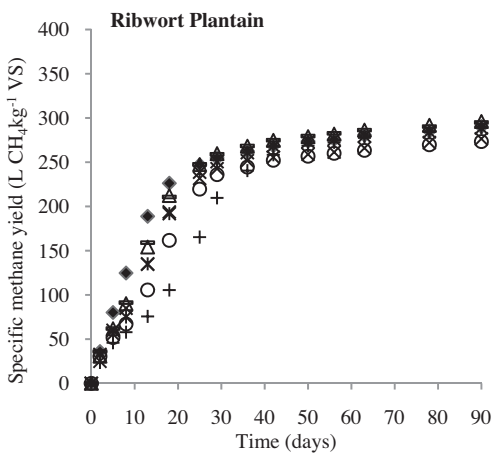

(c)

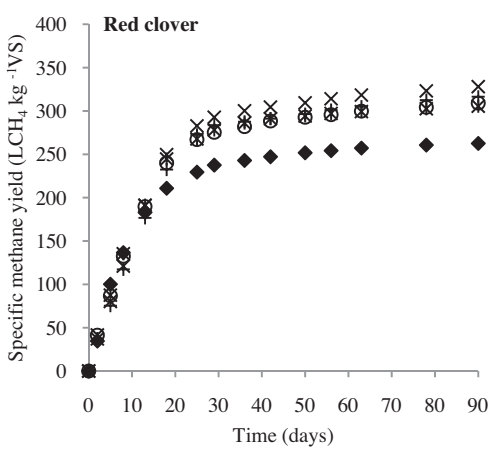

(d)

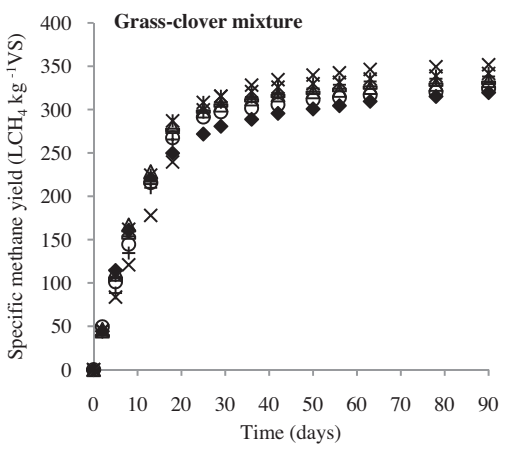

(e)

Fig. 3. Specific methane yield of (a) chicory, (b) caraway, (c) ribwort plantain, (d) red clover and (e) grass-clover mixture (up to 90 days).

maturity. High lignin content in the plant hinders hydrolysis of lignocellulosic materials (Prochnow et al., 2009); causing difficulties for hydrolytic bacteria to hydrolyse polysaccharide into soluble molecules of sugar. This limits degradation of forbs and grassclover mixture and causes low production of methane during anaerobic digestion. Kandel et al. (2013b) and Massé et al. (2010) observed decreased methane production as reed canary grass and switchgrass maturity (respectively) was increased.

The results were diverse for caraway and ribwort plantain (Fig. $3 b$ and $c$ ) as the differences in methane production rate were evident. It is interesting to observe variation in specific methane yield of these forbs. Thus, the experimental data was correlated with modified Gompertz models (Table 2). From the models, methane production rate, $\mu_{\mathrm{m}}\left(\mathrm{LCH}_{4} \mathrm{~kg}^{-1} \mathrm{VS} \mathrm{d}^{-1}\right)$ and lag phase, $\lambda$ (day) were estimated. The statistical data showed significant differences in $\mu_{\mathrm{m}}$ for forbs and grass-clover mixtures except red clover at different cutting period. The differences in $\lambda$ were only pronounced for caraway and ribwort plantain. In general, degradation of digested materials was faster when plants were harvested for the first time in the two-cut system. This observation might be due to high content of NDF as a result of high temperature and high global radiation during the growth period. In addition, lignin content was less compared to plants harvested in the one-cut system. Nevertheless, no specific trend correlating methane production rate with fibre compositions of forbs and grass-clover mixture at different cutting periods was found.

\subsection{Methane yield per hectare}

The potential of pure stand forbs as feedstock for anaerobic digestion in a biogas plant in terms of methane production per ha was estimated. Methane yield per hectare of forbs and grassclover mixture at three cutting managements are shown in Fig. 4 and Table 1 . Chicory, ribwort plantain and grass-clover mixture had higher methane yield per hectare when the two-cut system was applied, while the four-cut system of caraway led to $7 \%$ higher methane yield per ha than the two-cut system. As expected, methane yield per hectare increased when red clover was harvested four times. Although red clover and grass-clover mixture were greater in methane yield per hectare, if considering production of biogas from a forb-grass mixture, higher methane production is expected. Thus, for the forbs, the hypothesis that a two-cut strategy may be performed without major gas yield decline was confirmed. The hypothesis was confirmed for none of the species with a one-cut strategy.

\subsection{NIRS analysis}

The reference data used for NIRS analysis are tabulated in Table 3 while, the models with best validation statistics are summarised in Table 4. High $R^{2}$ and RPD and a low RMSE $\mathrm{CV}$ values were the indicator to measure the success of prediction. As observed, the application of pre-processing data treatment on raw data improved most of the models. In general, the best predictions of methane and biogas were obtained when triplicates samples (99 data) were used instead of individual 33 samples. The best prediction of methane and biogas models were achieved at 29 days using 99 samples, with $R^{2}$ of 0.93 and RPD of 4.91 (methane) and with $R^{2}$ of 0.86 and RPD of 2.57 (biogas). The results from this study was found higher than reported by Kandel et al. (2013b) and Raju et al. (2011). The differences might due to variations in reference data, sample types and homogeneity. Kandel et al. (2013b) analysed smaller reference data than Raju et al. and the present study (69 vs. 95 and 99 samples) and the mass of material used for each NIRS analysis and the surface area scanned was greater in this study than in these two previous studies, potentially increasing the representativity of the samples. In addition, Kandel et al. investigated only 
Table 2

Parameters of the mathematical adjustments, modified Gompertz.

\begin{tabular}{|c|c|c|c|}
\hline \multirow[t]{2}{*}{ Samples } & \multicolumn{3}{|l|}{ Modified Gompertz } \\
\hline & $\mu_{\mathrm{m}}\left(\mathrm{LCH}_{4} \mathrm{~kg}^{-1} \mathrm{VSd}^{-1}\right)^{*}$ & $\lambda(\mathrm{d})^{*}$ & $R^{2}$ \\
\hline \multicolumn{4}{|l|}{ Chicory } \\
\hline Cut $1 / 1$ & $12.24 \pm 0.91 \mathrm{c}$ & $0.00 \pm 0.00$ & 0.982 \\
\hline Cut $1 / 2$ & $16.75 \pm 1.25 \mathrm{ab}$ & $0.02 \pm 0.04$ & 0.992 \\
\hline Cut $2 / 2$ & $15.65 \pm 0.63 b c$ & $0.00 \pm 0.00$ & 0.991 \\
\hline Cut $1 / 4$ & $19.66 \pm 2.50 \mathrm{a}$ & $0.52 \pm 0.34$ & 0.996 \\
\hline Cut $2 / 4$ & $18.25 \pm 0.67 a b$ & $0.01 \pm 0.02$ & 0.994 \\
\hline Cut $3 / 4$ & $15.37 \pm 0.55 b c$ & $0.00 \pm 0.00$ & 0.992 \\
\hline Cut $4 / 4$ & $17.44 \pm 1.04 \mathrm{ab}$ & $0.00 \pm 0.00$ & 0.993 \\
\hline \multicolumn{4}{|l|}{ Caraway } \\
\hline Cut $1 / 1$ & $13.19 \pm 0.60 b$ & $0.00 \pm 0.00 \mathrm{~d}$ & 0.977 \\
\hline Cut $1 / 2$ & $15.97 \pm 0.33 a$ & $0.21 \pm 0.17 d$ & 0.994 \\
\hline Cut $2 / 2$ & $8.63 \pm 0.02 d$ & $2.73 \pm 0.10 \mathrm{~b}$ & 0.996 \\
\hline Cut $1 / 4$ & $12.03 \pm 0.41 c$ & $0.35 \pm 0.15 d$ & 0.996 \\
\hline Cut $2 / 4$ & $9.41 \pm 0.38 d$ & $1.50 \pm 0.35 c$ & 0.993 \\
\hline Cut $3 / 4$ & $7.38 \pm 0.14 \mathrm{e}$ & $4.83 \pm 0.38 a$ & 0.993 \\
\hline Cut $4 / 4$ & $8.55 \pm 0.54 d$ & $0.89 \pm 0.81 \mathrm{~cd}$ & 0.996 \\
\hline \multicolumn{4}{|c|}{ Ribwort plantain } \\
\hline Cut $1 / 1$ & $13.32 \pm 1.05 a$ & $0.00 \pm 0.00 b$ & 0.987 \\
\hline Cut $1 / 2$ & $12.09 \pm 0.30 \mathrm{ab}$ & $0.25 \pm 0.30 \mathrm{~b}$ & 0.995 \\
\hline Cut $2 / 2$ & $12.12 \pm 0.39 \mathrm{ab}$ & $0.42 \pm 0.09 b$ & 0.994 \\
\hline Cut $1 / 4$ & $11.05 \pm 0.36 b c$ & $0.46 \pm 0.34 b$ & 0.994 \\
\hline Cut $2 / 4$ & $11.14 \pm 0.21 b$ & $0.77 \pm 0.06 \mathrm{ab}$ & 0.995 \\
\hline Cut $3 / 4$ & $9.74 \pm 0.13 c$ & $1.05 \pm 0.28 \mathrm{ab}$ & 0.994 \\
\hline Cut $4 / 4$ & $8.19 \pm 0.24 d$ & $3.05 \pm 2.13 a$ & 0.993 \\
\hline \multicolumn{4}{|c|}{ Red clover } \\
\hline Cut $1 / 1$ & $13.56 \pm 0.93$ & $0.00 \pm 0.00$ & 0.982 \\
\hline Cut $1 / 4$ & $14.44 \pm 1.15$ & $0.00 \pm 0.00$ & 0.993 \\
\hline Cut $2 / 4$ & $14.94 \pm 0.65$ & $0.02 \pm 0.03$ & 0.993 \\
\hline Cut $3 / 4$ & $13.85 \pm 0.14$ & $0.00 \pm 0.00$ & 0.990 \\
\hline Cut $4 / 4$ & $13.39 \pm 0.20$ & $0.00 \pm 0.00$ & 0.993 \\
\hline \multicolumn{4}{|c|}{ Grass-clover mixture } \\
\hline Cut $1 / 1$ & $14.91 \pm 0.72 b c$ & $0.00 \pm 0.00$ & 0.978 \\
\hline Cut $1 / 2$ & $17.63 \pm 0.63 a$ & $0.00 \pm 0.00$ & 0.993 \\
\hline Cut $2 / 2$ & $18.17 \pm 0.86 a$ & $0.00 \pm 0.00$ & 0.990 \\
\hline Cut $1 / 4$ & $14.16 \pm 0.57 c$ & $0.00 \pm 0.00$ & 0.996 \\
\hline Cut $2 / 4$ & $18.26 \pm 1.08 \mathrm{a}$ & $0.00 \pm 0.00$ & 0.992 \\
\hline Cut $3 / 4$ & $16.67 \pm 0.47 a b$ & $0.00 \pm 0.00$ & 0.992 \\
\hline Cut $4 / 4$ & $16.11 \pm 0.92 \mathrm{abc}$ & $0.07 \pm 0.12$ & 0.994 \\
\hline
\end{tabular}

\pm Represents standard deviation.

${ }^{*}$ Means followed by different letter, ${ }^{\mathrm{a}-\mathrm{e}}$ in the row differ by Tukey test at 0.05 of probability. one species and Raju et al. used mostly mixed species, whereas the present study consists of pure stand species and a mixture. The pure stand species may have their own spectral signature that allow variations and easier to model using NIRS. Reduced homogeneity of the non-dried samples during the methane yield batch tests may also have contributed to less well-fitted model as reported in Raju et al.

Chemical compositions of forbs and grass-clover mixture were also model by NIRS. It was observed that $R^{2}$ and RPD values varied from 0.73 to 0.96 and 1.90 to 4.91 . The reference data used in this study had an extensive range of chemical composition (except C) as plants were harvested at the three cutting strategies. This explains good models with $R^{2}>0.70$ when NIRS was used to model the chemical compositions. The NDF, ADF and CP models predicted was comparable with Berardo (1997) as $R^{2}$ was higher than 0.90. In the Berardo (1997) study, 140 samples of white clover were evaluated to predict ADF, NDF, ADL and CP. However, the ADL model in present study has lower $R^{2}$ value (0.73) than in the previous study (0.83). This may be explained by the reference samples used in Berardo (1997), which had wider range as white clover was collected from two different locations for a period of 5 years.

The performance of models predicting biogas and methane yields based on fibre compositions were also evaluated in this study. The best prediction of biogas was obtained from lignin, with $R^{2}$ of 0.32 , while $R^{2}$ of 0.25 for methane predicted by ADF, NDF and lignin. This observation was parallel with Triolo et al. (2011) who found lignin to be the greatest predictor for biochemical methane potential (BMP) of energy crops, although a much better correlation was found with $R^{2}>0.76$. Triolo et al. used grass, maize and straw with different harvest time to model BMP by fibre fractions. The study confirmed that BMP was dependent on lignin concentration and fibre fractions could be use to predict BMP and biodegradability of biomass. In contrast, prediction of methane potential by NIRS was better in the present study than models using fibre fractions for prediction. Kandel et al. (2013a) suggested that spectral data from NIRS may contain additional information of the plant materials beside lignin, cellulose and hemicelluloses. This explained better performance of NIRS models as compared to models solely based on chemical compositions.

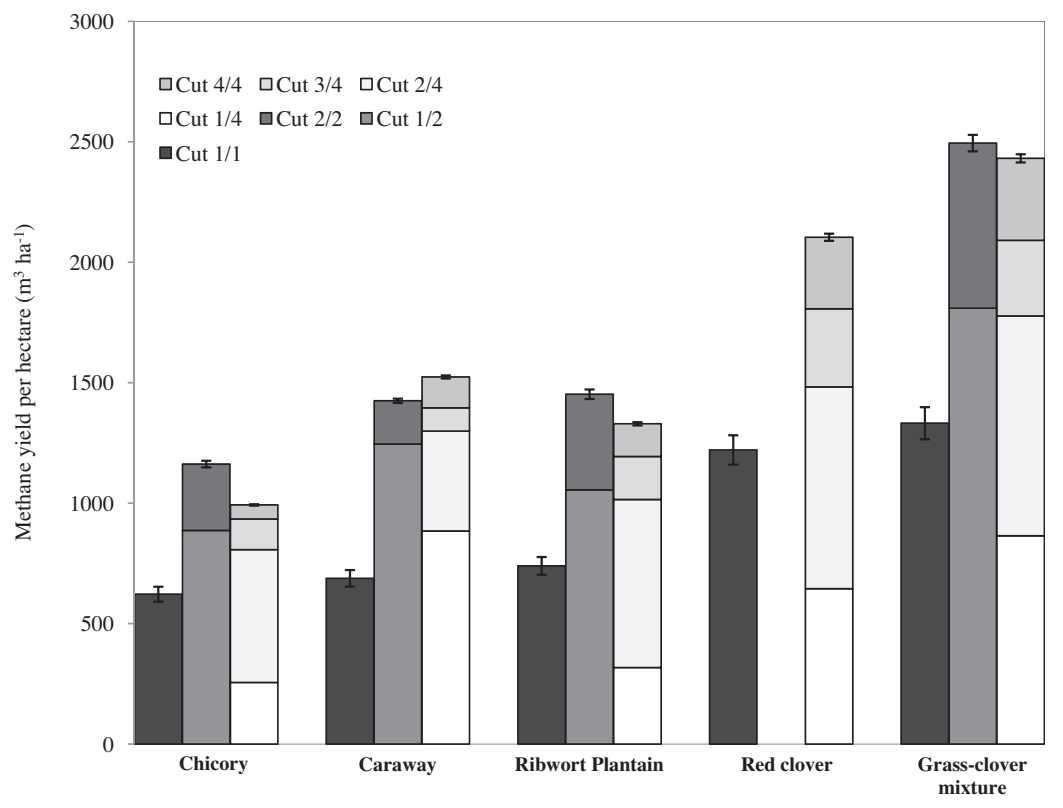

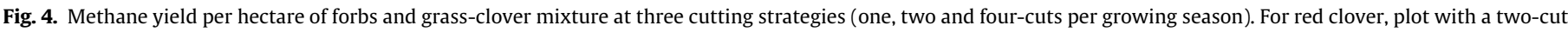
strategy was not established. 
Table 3

Characteristics of the samples - biogas, methane and chemical compositions.

\begin{tabular}{llrrrr}
\hline & $\begin{array}{l}\text { Number of } \\
\text { data samples }(n)\end{array}$ & Minimum & Maximum & Mean & Standard deviation \\
& 99 & 184.00 & 324.77 & 269.86 & 32.50 \\
Methane (29 days) & 99 & 254.91 & 362.78 & 308.88 & 23.61 \\
Methane (90 days) & 99 & 406.80 & 617.10 & 519.82 & 53.23 \\
Biogas (29 days) & 99 & 450.27 & 666.57 & 582.26 & 47.33 \\
Biogas (90 days) & 33 & 190.72 & 315.44 & 269.86 & 32.33 \\
Methane (29 days) & 33 & 262.59 & 351.66 & 308.80 & 22.23 \\
Methane (90 days) & 33 & 419.76 & 605.77 & 521.81 & 53.11 \\
Biogas (29 days) & 33 & 465.03 & 656.80 & 582.25 & 44.97 \\
Biogas (90 days) & 33 & 14.13 & 43.65 & 25.45 & 7.02 \\
Cellulose & 33 & 17.04 & 55.37 & 33.79 & 10.68 \\
Hemicellulose & 33 & 1.17 & 11.67 & 4.61 & 2.58 \\
Lignin & 33 & 19.18 & 65.60 & 38.40 & 12.56 \\
NDF & 33 & 16.26 & 54.89 & 30.07 & 9.35 \\
ADF & 33 & 41.70 & 46.04 & 43.92 & 1.14 \\
Carbon & 33 & 6.26 & 25.05 & 14.30 & 5.70 \\
Crude protein & & & & \\
\hline
\end{tabular}

Table 4

Validation statistics of PLS1 model.

\begin{tabular}{|c|c|c|c|c|c|c|}
\hline Models & $\begin{array}{l}\text { Number of } \\
\text { data samples }(n)\end{array}$ & Treatment & $\begin{array}{l}\text { Number of principle } \\
\text { component }\end{array}$ & $\mathrm{RMSE}_{\mathrm{CV}}$ & $R_{\mathrm{CV}}^{2}$ & $\mathrm{RPD}\left(\mathrm{SD} / \mathrm{RMSE}_{\mathrm{CV}}\right)$ \\
\hline NIR $\rightarrow$ methane (29 days) & 99 & SNV & 4 & 8.61 & 0.93 & 3.77 \\
\hline NIR $\rightarrow$ methane (90 days) & 99 & SNV & 8 & 12.39 & 0.72 & 1.91 \\
\hline NIR $\rightarrow$ biogas (29 days) & 99 & No-treatment & 11 & 20.31 & 0.86 & 2.57 \\
\hline NIR $\rightarrow$ biogas (90 days) & 99 & De-trend & 7 & 23.28 & 0.76 & 2.03 \\
\hline NIR $\rightarrow$ methane (29 days) & 33 & Savitzky-Golay & 4 & 21.63 & 0.57 & 1.49 \\
\hline NIR $\rightarrow$ methane (90 days) & 33 & Baseline & 4 & 16.57 & 0.46 & 1.34 \\
\hline NIR $\rightarrow$ biogas ( 29 days) & 33 & SNV & 2 & 42.57 & 0.38 & 0.76 \\
\hline NIR $\rightarrow$ biogas (90 days) & 33 & SNV & 6 & 33.81 & 0.45 & 1.33 \\
\hline NIR $\rightarrow$ cellulose & 33 & MSC & 10 & 2.20 & 0.90 & 3.19 \\
\hline NIR $\rightarrow$ hemicellulose & 33 & De-trend & 9 & 4.06 & 0.86 & 2.63 \\
\hline NIR $\rightarrow$ lignin & 33 & De-trend & 5 & 1.24 & 0.78 & 2.08 \\
\hline $\mathrm{NIR} \rightarrow \mathrm{NDF}$ & 33 & SNV & 6 & 3.12 & 0.94 & 4.03 \\
\hline $\mathrm{NIR} \rightarrow \mathrm{ADF}$ & 33 & MSC & 2 & 2.83 & 0.91 & 3.30 \\
\hline NIR $\rightarrow$ carbon & 33 & Baseline & 11 & 0.60 & 0.73 & 1.90 \\
\hline NIR $\rightarrow$ crude protein & 33 & Baseline & 11 & 1.16 & 0.96 & 4.91 \\
\hline ADF, NDF and lignin $\rightarrow$ biogas & 33 & Raw data & 1 & 39.63 & 0.25 & - \\
\hline ADF, NDF and lignin $\rightarrow$ methane (90 days) & 33 & Raw data & 1 & 19.91 & 0.22 & - \\
\hline Lignin $\rightarrow$ biogas & 33 & Raw data & 1 & 37.65 & 0.32 & - \\
\hline Lignin $\rightarrow$ methane (90 days) & 33 & Raw data & 1 & 20.10 & 0.21 & - \\
\hline NDF and lignin $\rightarrow$ biogas & 33 & Raw data & 1 & 39.90 & 0.24 & - \\
\hline NDF and lignin $\rightarrow$ methane (90 days) & 33 & Raw data & 1 & 20.65 & 0.16 & - \\
\hline
\end{tabular}

\section{Conclusions}

Cutting strategy has much greater influence on methane yield per ha than plant species. For chicory, plantain and caraway, gas yields in a two-cut system proved similar to those in a four-cut system on an area basis with the perspective of lowering costs per cubic meter of methane produced. Chemical compositions of the plants varied with respect to plant species, plant maturity and climate conditions. NIRS predictions of cellulose (RPD $=3.19)$, hemicelluloses $(\mathrm{RPD}=2.63)$, ADF $(\mathrm{RPD}=3.30)$, NDF $(\mathrm{RPD}=4.03)$ and $\mathrm{CP}(\mathrm{RPD}=4.91)$ were good. The gas yields were best predicted during the short term, although prediction at 90 days digestion is acceptable.

\section{Acknowledgements}

The authors wish to thank the post-doc, Cristiane de Almeida Neves Xavier and lab technician, Britt Amby Malthesen at Biogas Plant, Foulum, Aarhus University for assistance in biogas tests. The first author thanks for the PhD scholarship granted by Ministry of Higher Education, Malaysia. This study was supported finan- cially by the International Centre for Research in Organic Food Systems (GUDP project Multiplant).

\section{References}

American Public Health Association - APHA, 2005. Standard methods for the examination of water and wastewater, 21th ed. APHA, Washington.

Berardo, N., 1997. Prediction of the chemical composition of white clover by nearinfrared spectroscopy. Grass Forage Sci. 52, 27-32.

Buxton, D.R., 1996. Quality-related characteristics of forages as influenced by plant environment and agronomic factors. Anim. Feed Sci. Technol. 59, 37-49.

Dien, B.S., Jung, H.J.G., Vogel, K.P., Casler, M.D., Lamb, J.F., Iten, L.Sarath, G., 2006. Chemical composition and response to dilute-acid pretreatment and enzymatic saccharification of alfalfa, reed canary grass, and switchgrass. Biomass Bioenergy 30, 880-891.

Doublet, J., Boulanger, A., Ponthieux, A., Laroche, C., Poitrenaud, M., Cacho Rivero, J. A., 2013. Predicting the biochemical methane potential of wide range of organic substrates by near infrared spectroscopy. Bioresour. Technol. 128, 252-258.

Elgersma, A., Søegaard, K., Jensen, S.K., 2013. Herbage dry-matter production and forage quality of three legumes and four non-leguminous forbs grown in singlespecies stands. Grass Forage Sci. 69, 705-716.

Eriksen, J., Askegaard, M., Kristensen, K., 1999. Nitrate leaching in an organic dairy/ crop rotation as affected by organic manure type, livestock density and crop. Soil Use Manage. 15, 176-182.

Eriksen, J., Askegaard, M., Kristensen, K., 2004. Nitrate leaching from an organic dairy crop rotation; the effect of manure type, $\mathrm{N}$-input and improved crop rotation. Soil Use Manage. 20, 48-54. 
132

R. Wahid et al./Bioresource Technology 198 (2015) 124-132

Kamalak, A., Canbolat, O., Gurbuz, Y., Erol, A., Ozay, O., 2005. Effect of maturity stage on chemical composition, in vitro and in situ dry matter degradation of tumbleweed hay (Gundelia tournefortii L.). Small Ruminant Res. 58, 149-156.

Kandel, T.P., Gislum, R., Jørgensen, U., Lærke, P.E., 2013a. Prediction of biogas yield and its kinetics in reed canary grass using near infrared reflectance spectroscopy and chemometrics. Bioresour. Technol. 146, 282-287.

Kandel, T.P., Sutaryo, S., Møller, H.B., Jørgensen, U., Lærke, P.E., 2013b. Chemical composition and methane yield of reed canary grass as influenced by harvesting time and harvest frequency. Bioresour. Technol. 130, 659-666.

Kaparaju, P., Serrano, M., Angelidaki, I., 2010. Optimization of biogas production from wheat straw stillage in UASB reactor. Appl. Energy 87, 3779-3783.

Klimiuk, E., Pokój, T., Budzyński, W., Dubis, B., 2010. Theoretical and observed biogas production from plant biomass of different fibre contents. Bioresour. Technol. 101, 9527-9535.

Krapf, L.C., Gronauer, A., Schmidhalter, U., Heuwinkel, H., 2011. Near infrared spectroscopy calibrations for the estimation of process parameters of anaerobic digestion of energy crops and livestock residues. J. Near Infrared Spectrosc. 19, 479.

Lo, H.M., Kurniawan, T.A., Sillanpää, M.E.T., Pai, T.Y., Chiang, C.F., Chao, K.P.Wu, H.Y., 2010. Modeling biogas production from organic fraction of MSW co-digested with MSWI ashes in anaerobic bioreactors. Bioresour. Technol. 101, 6329-6335.

Marley, C.L., Fychan, R., Davies, J.W., Scollan, N.D., Richardson, R.I., Theobald, V.J. Sanderson, R., 2014. Effects of chicory/perennial ryegrass swards compared with perennial ryegrass swards on the performance and carcass quality of grazing beef steers. PloS One 9 (1).

Massé, D., Gilbert, Y., Savoie, P., Bélanger, G., Parent, G., Babineau, D., 2010. Methane yield from switchgrass harvested at different stages of development in Eastern Canada. Bioresour. Technol. 101, 9536-9541.

Mayer, F., Noo, A., Sinnaeve, G., Dardenne, P., Hoffmann, L., Flammang, J., Delfosse, P., 2011. Evaluation of the prediction of biogas production from maize silages with near infrared spectroscopy (NIRS). In: Proceedings of the International Congress Progress: Biogas II, pp. 235-240.

Mähnert, P., Heiermann, M., Linke, B., 2005. Batch- and semi-continuous biogas production from different grass species. Agric. Eng. Int. 9.
Møller, H.B., Sommer, S.G., Ahring, B.K., 2004. Methane productivity of manure, straw and solid fractions of manure. Biomass Bioenergy 26, 485-495.

Oleszek, M., Król, A., Tys, J., Matyka, M., Kulik, M., 2014. Comparison of biogas production from wild and cultivated varieties of reed canary grass. Bioresour. Technol. 156, 303-306.

Pirhofer-Walzl, K., Søegaard, K., Høgh-Jensen, H., Eriksen, J., Sanderson, M.A., Rasmussen, J., Rasmussen, J., 2011. Forage herbs improve mineral composition of grassland herbage. Grass Forage Sci. 66, 415-423.

Prochnow, A., Heiermann, M., Plöchl, M., Linke, B., Idler, C., Amon, T., Hobbs, P.J., 2009. Bioenergy from permanent grassland - a review: 1. Biogas. Bioresour. Technol. 100, 4931-4944.

Raju, C.S., Ward, A.J., Nielsen, L., Møller, H.B., 2011. Comparison of near infra-red spectroscopy, neutral detergent fibre assay and in-vitro organic matter digestibility assay for rapid determination of the biochemical methane potential of meadow grasses. Bioresour. Technol. 102, 7835-7839.

Seppälä, M., Paavola, T., Lehtomäki, A., Rintala, J., 2009. Biogas production from boreal herbaceous grasses - specific methane yield and methane yield per hectare. Bioresour. Technol. 100, 2952-2958.

Silva, F.D.A.E., Azevedo, C.D., 2006. A new version of the assistant-statistical assistance software. Paper presented at the World Congress on computers in agriculture.

Søegaard, K., Eriksen, J., Askegaard, M., 2011. Herbs in high producing organic grasslands - effect of management. Retrieved from: <http://orgprints.org/ 20685>.

Triolo, J.M., Sommer, S.G., Møller, H.B., Weisbjerg, M.R., Jiang, X.Y., 2011. A new algorithm to characterize biodegradability of biomass during anaerobic digestion: influence of lignin concentration on methane production potential. Bioresour. Technol. 102, 9395-9402.

Van Soest, P.J., Robertson, J.D., Lewis, B.A., 1991. Methods for dietary fiber, neutral detergent fiber and non-starch polysaccharide in relation to animal nutrition. J. Dairy Sci. 74, 3583-3597.

Wessa, P., 2012. Pearson correlation (v1. 0.6) in free statistics software (v1. 1.23-r7). Office for Research Development and Education. Retrieved from: <http://www. wessa.net/rwasp_correlation.wasp>. 